\title{
HELIODORO, AQUILES TACIO Y LOS PRECEPTISTAS ESPAÑOLES
}

JAVIER GONZALEZ ROVIRA

Para Antonio Cruz Casado

Sin lugar a dudas, la edición de las novelas de Heliodoro y Aquiles Tacio en el siglo XVI resultó determinante en la evolución del romance medieval hacia formas más cercanas a lo que conocemos por novela moderna. Baste tan sólo mencionar los estudios de Wolff, Molinié y Cruz Casado dedicados, respectivamente, a las narrativas inglesa, francesa y española para apreciar el alcance de dicho influjo ${ }^{1}$. Sin embargo, no ocurre lo mismo en la preceptiva poética. Como trataremos de analizar en estas páginas, muy pocos tratadistas de relieve supieron comprender la novedad de dichos modelos y continuaron anclados en su consideración de Homero y Virgilio como los mejores modelos para la narración. Hay que ir espigando entre textos menores de poética (prólogos, apologías, discusiones académicas...), debidos en su mayoría a creadores, para poder percibir la pe-

${ }^{1}$ Samuel L. WoLfF, The Greek Romances in Elisabethan Prose Fiction, New York, Columbia, 19612; Georges MolinIE, Du roman grec au roman baroque, Toulouse, Universite de Toulouse-Le Mirail, 1982, y A. CRUZ CASADO, «Los amantes peregrinos Angelia y Lucenrique», un libro de aventuras peregrinas inédito (tesis doctoral), Madrid, Universidad Complutense, 1989. Para un planteamiento general sobre la incidencia en Europa, vid. M. OEFTERING, Heliodor und seine Bedeutung für Literatur, Berlín, Felber, 1901, y C. GARCiA Gual, Los origenes de la novela, Madrid, Istmo, 19882; para España, Miguel Angel Telueiro, La novela bizantina. Apuntes para una revisión del género, Cáceres, Universidad de Extremadura, 1988. 
netración de la novela griega en las teorías literarias del Siglo de $\mathrm{Oro}^{2}$. Pero no se trata únicamente de un fenómeno hispano: frente a lo que cabría esperar, dado el importante desarrollo de las discusiones literarias a partir de las ediciones y comentarios de la Poética de Aristóteles, tampoco en Italia los modelos narrativos clásicos alcanzaron un lugar significativo en dichas manifestaciones. Como ejemplo más destacado, hay que recordar que una única mención a los novelistas griegos encontramos en los Discorsi del poema eroico tassianos ${ }^{3}$.

Dado que en las principales retóricas castellanas (Salinas, Espinosa, Guzmán, Jiménez Patón y Juan de Robles) no hemos encontrado ninguna alusión a los novelistas griegos ${ }^{4}$, nuestro análisis debe empezar por los primeros tratados de poética importantes: El arte poética en romance castellano de Sánchez de Lima (1580) y el Arte poética española de Díaz Rengifo, escrita en 1592, aunque publicada en 1606. En ninguno de los dos textos aparecen menciones a nuestros novelistas posiblemente porque se centran en cuestiones de versificación ${ }^{5}$, como ocurre en otros textos de la época ${ }^{6}$. No obstante, queremos señalar, a propósito

2 Como señala Vilanova, la teorfa y la práctica literaria discurrieron en España por sendas distintas («Preceptistas españoles de los siglos XVI y XVII», en G. DIAZ PLAJA, Historia general de las literaturas hispánicas, Barcelona, Vergara, 1953, vol. III, pp. 567-569, especialmente).

${ }^{3}$ «Concedasi dunque che 'l poema epico si possa formar di soggetto amoroso, com' è l'amor di Leandro e d'Ero, de' quali canto Museo antichissimo poeta greco; e quel di Giasone e di Medea, dal quale prese il soggetto Apollonio fra' Greci e Cornelio Flacco tra' Latini; o quel di Alessandro e d'Elena descritto da Coluto Tebano e dal cardinale Sfondrato padre di Gregorio XIIII, non solo a' suoi tempi grandissimo prelato, ma grandissimo poeta; o quelli di Teagene e di Cariclea, e di Leucippe e di Clitofonte, che nella medesima lingua furono scritti per Eliodoro e per Achille Tazio [...]». TORQUATo TASso, Scritti sull' arte poetica, ed. de E. Mazzali, Torino, Einaudi, 1977, vol. I, p. 205-206. No hemos encontrado ninguna alusión al novelista de Émesa en las principales poéticas y tratados del siglo XVI que hemos podido consultar: Robortello, GiRaldi Cintio, MuZio, Minturno, Leonardi, Salviati, Neroni y Bonciani.

${ }^{4}$ Exceptuamos de nuestro estudio el importantísimo prólogo de AMYoT a su traducción francesa de Las etiopicas (París, 1547), reproducido en la primera versión española (Amberes, 1554; editado por LOPEZ ESTRADA en su estudio preliminar en Heliodoro, Historia etiópica de los amores de Teágenes y Cariclea, Madrid, Real Academia Española, 1954, pp. LXXVII-LXXXIII) por tratarse, doblemente, de una traducción: de Heliodoro, donde es indudable que aparecerán menciones a la narrativa griega; y de un texto de un erudito no español, campo al que limitaremos nuestro estudio. No aparecerán tampoco, salvo excepciones, las alusiones circunstanciales (aspectos estilísticos, elogios, etc.) que no se refieran a cuestiones de poética.

${ }^{5}$ No obstante, una de las primeras menciones que conocemos a la obra de Heliodoro se refiere a una cuestión de métrica: la posibilidad de trasladar el hexámetro al castellano. Se encuentra en los Diálogos de la montería (Madrid, Sociedad de Bibliófilos Españoles, 1890, p. 226) atribuidos a Barahona de Soto y fechados entre 1568 y 1582: «en la traducción de la Etiópica de Heliodoro hay otros versos de esta suerte traducidos de griego á latín y de ahf á español».

6 Tampoco aparecen menciones a los novelistas griegos en el Discurso sobre la poesía castellana de ARGOTE DE MOLINA (1575) ni en la anónima Arte poética castellana editada por V. INFAN- 
de la obra de Díaz Rengifo, un detalle de interés: la existencia de otros personajes históricos con el mismo nombre que el autor de Las etiópicas, lo que puede llevar a confusiones ${ }^{7}$. En efecto, en la «Silua de consonantes copiosissíma» de dicha poética encontramos a cierto «Heliodoro» $^{8}$, pero extrañamente no aparecen ni Teágenes ni Cariclea en este extenso rimario, cuando es muy frecuente la mención a personajes literarios de la antigüedad. La aclaración puede deducirse de la «Explicación de los consonantes propios que van en la Sylua» que acompaña a las listas de rimas ya que se especifica que se trata de «Heliodoro, retórico»?.

Se nos presentan dos posibilidades de identificación de este Heliodoro. En primer lugar, puede tratarse de «Heliodoro el árabe» mencionado por Filóstrato, un sofista que en algunas ocasiones ha sido identificado con el novelista de Émesa ${ }^{10}$. Pero una hipótesis que nos parece mucho más probable es que se trate del poeta griego autor de los Spectaculis Italicis mencionado por Estobeo ${ }^{11}$, que quizá sea el «rhetor Heliodorus» que aparece en las Sátiras de Horacio ${ }^{12}$, autoridades sin duda mucho más conocidas en la Edad de Oro. Caramuel, muchos años después, copiará y ampliará la obra de Díaz Rengifo, por lo que también podremos encontrar al «Heliodoro rhetórico» en el rimario y la silva de la segunda parte de su Primus calamus (1665) ${ }^{13}$.

TES (Studi ispanici, 1989, pp. 145-161). Destaquemos que tampoco los cita HERRERA en sus Anotaciones a Garcilaso de la Vega (1580).

${ }^{7}$ Por ejemplo, CARILLA («La novela bizantina en España», RFE, XLIX [1966], p. 280) y TEIJEIRo (op. cit., p. 61) identifican al Heliodoro que aparece en el poema de Pedro de Espinosa «Soledad de Pedro de Jesús, presbítero" con el novelista de Émesa. Pero, como señala LóPEZ EsTrada (en su introducción a Pedro de Espinosa, Poesias completas, Madrid, Espasa-Calpe, 1975, p. XLII) "conviene recordar que el nombre poético de Heliodoro que da al duque es el de un corresponsal de San Jerónimo en sus Epístolas (libro III, epístola I)».

${ }^{8}$ Juan Diaz Rengifo, Arte poética española, Madrid, Juan de la Cuesta, 1606, p. 232.

${ }^{9}$ Ibid., p. 350 .

${ }^{10}$ No creemos que dicha identificación sea del todo correcta, ya que no coinciden las noticias que tenemos sobre el novelista de Émesa con las que ofrece Filostrato en su Vida de los sofistas (Madrid, Gredos, 1982, pp. 246-248), quien no menciona ninguna obra de dicho retórico y de quien afirma que «envejece ahora en Roma, ni tenido por hombre eminente ni despreciado», mediocre fama, creemos, para nuestro novelista.

${ }^{11}$ Ioannis STOBAEI, Sententiae ex thesavris graecorum collectae, trad. Conradum Gesnerum, Parisiis, Martinum Iuuenem, 1552, p. 843 (sermo XCVIII), donde reproduce dieciséis versos de dicha obra. En la edición de H. Grotio (Dicta poetarvm, Parisiis, Nicolavm Bvon, 1623, p. 420) aparece en el titvlus $\mathrm{C}$.

12 En los primeros versos de su sátira V (libro primero) leemos: «Egressum magna me accepit Aricia Roma / hospitio modico; rhetor comes Heliodorus, / graecorum longe doctissimus» (las cursivas son nuestras). Horace, Satires, ed. de F. Villeneuve, Paris, Les Belles Lettres, $1962^{6}$.

13 Ioannis Caramvelis, Primvs Calamvs. II Rhythmicam, Sanctum Angelvm della Fratta, 1665 , pp. 456 y 498. 
Pero, retomando el hilo temporal que pretendemos dar a estas páginas, antes de la poética de Díaz Rengifo ha aparecido la excepción en todo este panorama que estamos trazando: la Philosophía antigua poética (1596) de Alonso López Pinciano, para quien Las etiópicas son un punto de referencia constante, como demuestran las cerca de veinte menciones a Heliodoro, a quien sitúa repetidas veces casi al mismo nivel que Homero y Virgilio, los modelos de mayor prestigio en la época. Pero lo más importante es que algunas de estas alusiones establecen ciertas diferencias entre novela y épica clásica que, a nuestro juicio, constituyen uno de los puntos de partida para la teoría poética y la práctica narrativa del Barroco. Como han puesto de relieve algunos estudios de cervantistas $^{14}$, López Pinciano, aunque de forma no sistemática, establece los principales rasgos característicos de la narración griega. Sus ideas, que iremos viendo repetidas durante los años siguientes, pueden resumirse en los siguientes aspectos:

1. La obra de Heliodoro, como la de Tacio, es una forma de poesía en prosa: «he caydo en la cuenta que la Historia de Ethiopía es vn poema muy loado, mas en prosa» ${ }^{15}$. En concreto, pertenecen ambas a la épica, aunque su estilo no requiere ser el sublime como parecía ser obligado para la epopeya:

en los poemas sin metro, no es necessario el alto lenguaje y peregrino, como lo vemos en Heliodoro y otros; los quales no fueron muy altos en el lenguaje, ni peregrinos, y especialmente, en la grandeza que del cuerpo se toma ${ }^{16}$.

${ }^{14}$ Nos referimos especialmente a Jean F. Canavaggio, «Alonso López Pinciano y la estética literaria de Cervantes en el Quijote», Anales Cervantinos, VII (1958), pp. 13-107; Alban K. Forcione, Cervantes, Aristotle and the «Persiles», Princeton, Princeton University Press, 1970; Edward C. Riley, Teoria de la novela en Cervantes, Madrid, Taurus, 1989 y A. Cruz Casado, «Para la poética de la narrativa de aventuras peregrinas», en M. GARcía Martín, ed., Estado actual de los estudios sobre el Siglo de Oro, Salamanca, Universidad de Salamanca, 1993, vol. I, pp. 261-265.

15 A. López Pinciano, Philosophia antigua poética, ed. de A. Carballo, Madrid, C.S.I.C., 1973, vol. I, p. 206. «Ni aun esso tampoco, dixo Vgo, admito; que sería hazer el metro necessario para la Poética; lo qual ni Aristóteles hizo, ni aun graue varón alguno; y sería que ni los Diálogos de Platón, ni las Fábulas de Esopo, ni las Milesias, ni la Historia de Ethiopía y otras assí fueran poemas; y sería que ni la Vlysea de Homero, que anda en prosa, ni Quinto Calabro, ni otros infinitos lo fuessen» (ibid., vol. III, p. 278).

16 lbid., vol. II, 184. Posteriormente insiste en la misma idea: «no tiene la grandeza necesaria; no digo en el lenguaje, que por no ser en metro está desculpado» (ibid., vol. III, p. 224), aunque también sostiene que es «fino poeta», en cuyo estilo se encuentran «muy buen lenguaje y muy altas sentencias» (ibid., vol. III, 167). 
2. Frente a las discusiones sobre la necesidad de una base histórica para la epopeya, observable en Homero y Virgilio, la verosimilitud de la novela del «prudentísmo» Heliodoro radica en la distancia espacio-temporal de la acción respecto al lector, quien no puede verificar la falsedad de la misma: «puso reyes de tierra ignota, y de quienes se puede mal aueriguar la verdad o falsedad, como antes está dicho, de su argumento» ${ }^{17}$.

3. Atendiendo a la materia de la fábula, es posible establecer una clasificación de la épica en tres subgéneros: "vnos poetas tratan materia de religión, [...] otros casos amorosos, como Museo, Heliodoro y Aquiles Tacio; otros, batallas y victorias, como Homero y Virgilio». Por otro lado, temática amorosa no indica superficialidad, sino que como puede verse en los modelos mencionados «debaxo de aquella paja floxa, ay grano de mucha sustancia» ${ }^{18}$.

4. El principio in medias res de Las etiópicas es superior incluso al de las obras de Homero y Virgilio:

Heliodoro guardó esso más que ningún otro poeta, porque Homero no lo guardo con esse rigor, a lo menos en la llíada, ni aun en la Vlysea si bien se mira; y, si miramos a Virgilio, tampoco començó del medio $^{19}$.

Como ya señalara Scaligero (1561), acérrimo panegirista de Virgilio, Heliodoro es quizá el mejor modelo para el inicio de los poemas épicos ${ }^{20}$.

5. La habilidad del autor de Las etiópicas radica especialmente en la resolución de una complicada trama. Utilizando la terminología aristotélica para

${ }^{17}$ Ibid., vol. III, p. 195. La idea recorre toda la obra del Pinciano: «es fingida toda hasta en los nombres y es de los mejores [poemas] que ha auido en el mundo [...] Theágenes no era tan gran príncipe que se deviera tener el nombre suyo en memoria y fama [...]; y Chariclea, heredera del reyno de Ethiopía era de quien acá y en la Grecia aúa poca noticia, y con fingir Reyna y Princesa de tierras ignotas, cumplió con la verisimilitud el poeta, porque nadie podría dezir que en Ethiopía no huuo rey Hydaspes, ni reyna Persina (ibid., vol. II, p. 331). Vid. también vol. III, pp. 165-166.

18 Ibid., vol. III, pp. 180-181.

${ }^{19}$ Ibid., vol. III, p. 207.

20 J. C. Scaligero, en los Poetices libri septem (Lipsiae [s.e.], 1561, p. 144), destaca la ejemplaridad de dicho inicio: «Hoc ipsum igitur quod pro principio sumes, ne statuas in principio, ita enim auditoris animus est suspensus: querit enim quod nondum extat. Ea sanè vel vnica vel praecipua virtus, auditorem quasi captiuum detinere. [...] Hanc disponendi rationem splendidissimam habes in Aethiopica historia Heliodori. Quem librum epico Poetae censeo accuratissime legendum, ac quasi pro optimo exemplari sibi proponendum.» 
el drama, el desenlace o soltura del nudo basado en la anagnórisis de Cariclea respeta la verosimilitud y prescinde del deus ex machina ${ }^{21}$.

6. Por último, el relato intradiegético, rasgo propio de la narración mixta de la epopeya, ejemplificado con los de Calasiris, Ulises y Eneas, aporta verosimilitud, variedad y dẹcoro ${ }^{22}$, pero lo que es más importante, incide en la implicación emocional del receptor ${ }^{23}$.

En síntesis, pocos preceptistas son capaces de desarrollar un análisis tan penetrante de la novela griega como el elaborado por López Pinciano y que hemos tratado de resumir en sus líneas generales. Frente a quienes repiten incansablemente los preceptos aristotélicos, el Pinciano abre las puertas de la imaginación a la narrativa y le confiere dignidad con su defensa e ilustración de la novela griega. Los ecos de su obra empezarán a escucharse inmediatamente. En 1602 encontramos ya un breve texto en la edición de La hermosura de Angélica de Lope de Vega, uno de los autores que más veces mencionará a los modelos griegos, donde se señala esta identificación de la novela de Heliodoro como prosa poética ${ }^{24}$, idea que, sin mencionar al novelista de Émesa, repetirá también Cervantes en su diseño del libro de caballerías ejemplar que encontramos en la primera parte del Quijote $(1605)^{25}$. Como veremos, se trata de un tópico que alcanza su mayor difusión en la década siguiente.

21 «La Historia de Heliodoro épica es, mas si bien se mira, atando va siempre, y nunca jamás desata hasta el fin. [...] Don del sol es Heliodoro, y en esso del ñudo y soltar nadie le hizo ventaja, y, en lo demás, casi nadie. [...] en toda acción conuiene yr apretando y estrechando este nudo, [...] especialmente en las acciones dramáticas y representatiuas, que todo se guarda hasta el tiempo de la soltura, para lo qual deue quedar siempre vn cabo de donde asir, que, con mucha presteza tirado, deshaga el ñudo súbitamente, [...] porque ay en esto del añudar y soltar algunos errores». Ibid. vol. II, pp. 85-86.

22 «Del narrar la cosa por persona agena del poeta nacen muchas cosas buenas a la accion; primeramente que, hablando assi, le es más honesto el alabar o vituperar las cosas que ama y aborrece, y dar su sentencia y parecer más libre; lo otro, que, dichas por vna y otra persona, varía la lección y no cansa tanto como si él solo fuesse el que narrasse». Ibid., vol. III, 208-209.

23 lbid., vol. II, p. 209: "para el mouimiento de los affectos es importantíssimo, porque, si otro que Vlyses contara sus errores y miserias, y otro que Eneas contara sus trabajos y desuenturas, no fuera la narración tan miserable, y, como deleyte de la épica, ansí como de la trágica, viene parte de la compassión y misericordia, faltara mucho al deleyte de la tal acción». Observemos la modernidad de este planteamiento de la recepción de la obra: como ha estudiado M. FussiLlo, $l l$ romanzo greco. Polifonia e eros, Venezia, Marsilio, 1989, Cnemón funciona como «lector implícito» que anticipa las reacciones del lector real y recibe las orientaciones de Calasiris.

24 LOPE DE VEGA, La hermosura de Angélica con otras rimas, Madrid, Pedro de Madrigal, 1602, fol. $337 \mathrm{v}^{\text {e: }}$ «la prosa suele hartas vezes hurtar a la poesía sus licencias, como en Heliodoro, Apuleyo y muchos de los modernos».

25 Miguel de Cervantes, Don Quijote de la Mancha, ed. de M. de Riquer, Barcelona, Planeta, $1981^{2}$, p. 520: «la épica también puede escrebirse en prosa como en verso». 
En el mismo año que las Rimas de Lope aparece una de las poéticas más importantes de nuestro Manierismo: el Cisne de Apolo de Luis Alfonso de Carballo. En esta obra encontramos una única mención a cierto Heliodoro que ha sido interpretada en varias ocasiones como una referencia al novelista de Éme$\mathrm{sa}^{26}$. En su defensa de la poesía, sostiene Carballo:

Galeno en muchas partes alega a Seruilio, y a Heliodoro, y a otros poetas, que en la Medicina mostraron el primor de la Poesía, y por tan diuinos, y de tanta virtud tuuieron antiguamente los versos, que entendían que las llagas se podían curar con ellos, y reprimir la sangre, solo con dezirlos ${ }^{27}$.

Como vemos, se trata de una cita indirecta, lo que de entrada ya le resta importancia como reflejo de la incidencia de la novela griega en nuestros preceptistas. Pero es que, además, es absolutamente imposible que esté haciendo referencia a Heliodoro de Émesa: Galeno murió mucho antes de que Las etiópicas fueran escritas. Se trata, nuevamente, de un Heliodoro distinto, en concreto de un físico y médico griego al que Galeno dedica numerosas menciones e, incluso, un libro completo: el Oribasius ex Heliodoro de Machinementis. En otros textos posteriores podremos encontrar referencias similares a Galeno o este «Heliodoro ateniense», dentro de una corriente de dignificación de la poesía que insiste en el poder curativo de la palabra ${ }^{28}$, como podemos ver en Vera y Mendoza ${ }^{29}$, y en Gutierre Marqués de Careaga, este último indicándonos una posible fuente de Carballo: André Tiraqueau, jurista francés cuyos Tratados se reeditaron frecuentemente durante el siglo $\mathrm{XVI}^{30}$.

26 A. Porqueras, La teoría poética en el Manierismo y Barroco españoles, Barcelona, Puvill, 1986, p. 28; A. Egido, Fronteras de la poesia en el Barroco, Barcelona, Crítica, 1990, p. 107.

${ }^{27}$ Luis alfonso de Carballo, Cisne de Apolo, ed. de A. Porqueras, Madrid, C.S.I.C., 1958, vol. I, p. 135.

${ }^{28}$ Para los antecedentes clásicos de este aspecto, vid. PEDro LAfN ENTRALGo, La curación por la palabra en la antigüedad clásica, Barcelona, Anthropos, 1987.

${ }^{29}$ En su Panegyrico por la poesía (Montilla, 1627, fol. $24 \mathrm{r}^{\circ}$ ) indica: «es la poesía acertadíssimo Galeno, disimulando las purgas para curarnos no solo los cuerpos, sino más perfecta parte que es el alma», y añade páginas después (ibid., fols. $30 \mathrm{r}^{\circ}-30 \mathrm{v}^{\circ}$ ): «y que den salud al cuerpo dize Galeno de Esculapio que para ablandar a ciertos enfermos vnas cóleras adustas, les recetó versos por pítima eficaz», remitiendo a De Sanitate tvenda libri sex de Galeno. Affade otras autoridades como Aulio Gelio, Plinio, etc.

${ }^{30}$ En La poesía defendida y difinida, Montalbán alabado (1639), sostiene Careaga: «no es digno de pasar en silencio (porque se diga todo) lo que no callo [...] Andrés Tiraquelo en sus tratados varios, que alabando a la medicina y a los médicos, por su mayor encomio, dice que muchos 
Tampoco muestran interés por los novelistas griegos las dos preceptivas más importantes de la década siguiente. Nos referimos al Libro de la erudición poética (1611) de Luis Carrillo y Sotomayor, dedicado integramente a la dicción del poema sublime y donde, en consecuencia, cabría esperar alguna mención a dichos modelos, aunque sólo fuera para rechazar la posibilidad de una poesía en prosa. Mayor sorpresa deparan las Tablas poéticas (1617) de Francisco de Cascales, obra con pretensiones mucho más amplias y donde tampoco encontramos las referencias que nos interesan. Es posible que este hecho se deba a dos causas: la temprana redacción de este tratado (hacia 1604) y su constante dependencia de poéticas italianas donde tampoco se presta atención a dichos modelos (especialmente, Robortello y Minturno). Pero sigue sorprendiendo que en sus Cartas filológicas (1634), donde aborda cuestiones como el principio in medias res, sólo aparezca una alusión circunstancial a Aquiles Tacio ${ }^{31}$.

Debemos fijar nuestra atención de nuevo en textos de otra índole para encontrar en estos años menciones de interés. Soto de Rojas, en una discusión académica fechada en 1612, donde resume las principales ideas de Aristóteles, realiza una escueta mención a lo que se está convirtiendo ya en un tópico: «también hay poetas en prosa, como son Heliodoro, Lucio Apuleyo, Doroteo y otros muchos» ${ }^{32}$. Mayor importancia tiene el conocido diálogo entre Nise y Celia en La dama boba (1613) de Lope de Vega, verdadera síntesis de los aspectos destacados por López Pinciano en su Philosophía: poesía en prosa, diferencias con la prosa histórica, dignidad del argumento amoroso, inicio in medias res $y$ ornato propio de estas obras ${ }^{33}$. En estos años parece crecer el interés

dellos fueron poetas». Y en la larguísima lista que sigue aparecen también Servilio y «Heliodoro Ateniense» (en A. PORQUeras MAYo, op. cit., p. 277).

31 Se refiere a Tacio en dichas Cartas filologicas (Madrid, Espasa-Calpe, 1969 ${ }^{3}$, vol. I, pp. 99-100) para aclarar el significado del adjetivo rubicundiores: «no dijeran esto si hubieran pasado los ojos por Aquiles Tacio, de quien sabemos que los Tirios solían teñir de púrpura el marfil bueno $y$ fino».

32 Puede verse el texto en Jose Sánchez, Academias literarias del Siglo de Oro, Madrid, Gredos, 1961, p. 101. Este breve compendio fue también recogido por su autor como preliminar en su Desengaño de amor en rimas (1623).

33 Lope DE VegA, La dama boba (ed. de D. Marín, Madrid, Cátedra, 19826 , pp. 74-75): «Nise: Heliodoro, / griego poeta divino. / Celia: ¿Poeta? Pues parecióme / prosa. Nise: También hay poesía / en prosa. Celia: No lo sabía. / Miré el principio, y cansóme./ Nise: Es que no se da a entender, / con el artificio griego, / hasta el quinto libro, y luego / todo se viene a saber / cuanto precede a los cuatro. / Celia: En fin, ¿es poeta en prosa? / Nise: Y de una historia amorosa / digna de aplauso y teatro. / Hay dos prosas diferentes: / poetica y historial. / La historia, lisa y leal, / cuenta verdades patentes, / con frase y términos claros; / la poetica es hermosa, / varia, culta, licenciosa, / y escura aun a ingenios raros. / Tiene mil exomaciones / y retóricas figuras». 
por la novela griega. El anuncio de Cervantes de su Persiles («libro que se atreve a competir con Heliodoro») en el prólogo de las Novelas ejemplares (1613) se anticipa al fugaz éxito editorial de la novela griega que explica en buena parte la proliferación de menciones en años posteriores: Teágenes y Cariclea se reedita en 1614, 1615 y 1616, mientras que en 1617 aparece la traducción española completa de Leucipe y Clitofonte, aunque no volverán a publicarse hasta el siglo XVIII ${ }^{34}$.

Otra alusión relevante la encontramos en el romance de Carlos Boyl $A$ un licenciado que deseaba hazer comedias (1616):

La suspensión hasta el fin / el autor de Clariclea / en Teagenes confirma / lo que en esto el gusto alienta. / Que conocer al principio / los sucesos del fin della, / ni es de mano artificiosa / ni es obra de ingenio llena ${ }^{35}$.

Como podemos observar, Boyl destaca del principio de Las etiópicas precisamente el efecto que dicho recurso suscita en la sensibilidad del lector 0 , en este caso, del espectador, algo ya señalado por Scaligero, como hemos indicado. Precisamente a este aspecto hará referencia el autor de la Expostulatio Spongiae (1618) cuando recuerda que «Epicis Scaliger Aethyopicam Heliodori proponit exemplar» ${ }^{36}$. A una forma distinta de suspensión se refiere también Lope de Vega en una de sus novelas cortas, Las fortunas de Diana, incluida en La Filomena (1621), donde reflexiona sobre el efecto que produce el entrelacement de las dos tramas focalizadas sobre cada uno de los protagonistas, recurso característico de la novela griega, como ha estudiado Hägg ${ }^{37}$. Lope, interrumpiendo su relato, indica:

34 Para las ediciones españolas de Heliodoro y Aquiles Tacio, vid. el estudio de Teijeiro citado en nuestra nota 1 , especialmente pp. 37-46, y nuestra nota «Una edición olvidada de Téagenes y Cariclea de Heliodoro», BBMP (en prensa).

35 Prosigue con una indicación sobre el destinatario de este tipo de recursos: «la suspensión / de un cabello al vulgo cuelga». El romance ha sido editado por SANCHEZ ESCRIBANO y PORQUERAS Mayo en su libro Preceptiva dramática española, Madrid, Gredos, 1972², pp. 181-185.

36 Texto editado en apéndice por MARGARETE NewELs, Los géneros dramáticos en las poéticas del Siglo de Oro, Londres, Tamesis Books, 1974, p. 186.

37 Tomas HÄG, Narrative Technique in Ancient Greek Romances. Studies of Chariton, Xenophon Ephesius and Achilles Tatius, Stokholm, Instituti Atheniensis Regni Sueciae, 1971. Vid. también CONSUElo RuIz-MONTERo, La estructura de la novela griega, Salamanca, Universidad de Salamanca, 1979, y M. PUlQUÉRIO FUTRE PINHEIRO, Estructuras técnico-narrativas nas «Etiopicas* de Heliodoro (tesis doctoral), Lisboa, Universidad de Lisboa, 1987. 
¿Quién duda, señora Leonarda, que tendrá vuestra merced deseo de saber qué se hizo nuestro Celio [...], pareciéndole que se ha descuidado la novela? Pues sepa vuestra merced que muchas veces hace esto mismo Heliodoro con Teágenes, y otras con Clariquea, para mayor gusto del que escucha, en la suspensión de lo que espera ${ }^{38}$.

Precisamente en estos años aparece una mención importante al inicio in medias res en uno de los primeros textos pertenecientes a una corriente donde Heliodoro desempeñará un destacado papel como autoridad hasta bien entrada la década siguiente: los comentaristas de Góngora. Como señala A. Cruz Casado, entre el grupo de defensores del autor del Polifemo será frecuente la mención del novelista de Émesa para justificar alguna de las novedades de los poemas gongorinos o algún rasgo estilístico ${ }^{39}$. Aunque no podemos precisar completamente la cronología de todos estos textos, ya que algunos se conservan manuscritos, desde la aparición de los primeros textos sobre las Soledades hasta las Lecciones solemnes $(1630)^{40}$, son varios los comentaristas que utilizarán el modelo de Las etiópicas.

Francisco Fernández de Córdoba, quien ya había mostrado su familiaridad con Heliodoro en su Didascalia multiplex (1615), aunque no en cuestiones de poética, alude al mismo en su Examen del «Antídoto» (c. 1617) dedicado a replicar a los violentos ataques de Jáuregui en su Antídoto contra la pestilente poesía de las "Soledades». En dicho Examen, Fernández de Cordoba justifica la identidad diferida del protagonista del poema basándose en el inicio in medias res heliodoriano ${ }^{41}$. Pero el texto más destacado en nuestra opinión es el de

38 LOPE DE VEGA, Obras poéticas, ed. de J.M. Blecua, Barcelona, Planeta, 1983, p. 691.

39 Vid. «Góngora a la luz de sus comentaristas (La estructura narrativa de las Soledades)», Dicenda, 5 (1986), pp. 49-70; «Las Soledades de Góngora y la narrativa de aventuras peregrinas», El Barroco en Andalucía, vol. VII, Córdoba, Universidad de Córdoba, 1987, pp. 145-160; y especialmente «Hacia un nuevo enfoque de las Soledades de Góngora: los modelos narrativos», Revista de Literatura, LII (1990), pp. 67-100. Además de los textos que mencionaremos, alude Cruz al manuscrito Apología en favor de don Luis de Góngora (1627) de Francisco Martínez de Portichuelo, indicando que hay una mención a Heliodoro y un fragmento de la traducción latina en fol. $25 \mathrm{v}^{\circ}$. Joaquín Roses ha editado fragmentos de dicha Apología (Criticon, 55 [1992], pp. 91-130), pero no aparece el texto mencionado.

${ }^{40}$ Dado que no se refiere a ninguna cuestión de poética, nos abstenemos de mencionar ejemplos de Pellicer quien, por otra parte, en otras obras suyas como El fénix y su historia natural o la Vida de Don Luis de Góngora (ambas de 1630) menciona a nuestros novelistas. Por otro lado, destaquemos que otro comentarista, esta vez de Garcilaso, menciona de forma circunstancial a Heliodoro en cuatro ocasiones y una a Aquiles Tacio: nos referimos a TAMAYO DE VARGAS y sus Notas a Garci-Lasso de la Vega, príncipe de los poetas castellanos (1622).

41 «Si en la primera [parte], que sola oy a salido a luz, este mançebo está por baptiçar, tenga V. m. paciencia, que en la segunda o la tercera se le baptiçarán y sabrá su nombre, pues Heliodoro 
otro ilustre comentarista, Pedro Díaz de Ribas, quien en sus Discursos apologéticos por el estilo del «Polifemo» y «Soledades», fechados en 1624, aunque redactados posiblemente hacia 1618, remite también a Heliodoro, tras citar el ya mencionado pasaje de los Discorsi de Tasso, para dignificar la materia amorosa como propia del poema heroico ${ }^{42}$. En otro texto, las Anotaciones y defensas a la primera Soledad de don Luis de Góngora, el abad de Rute vuelve a citar al novelista de Émesa como modelo para el inicio in medias res ${ }^{43}$.

Paralelamente, ya en la década de 1620-1630, seguimos encontrando nuevos textos que aluden a los novelistas griegos en la defensa o justificación de aspectos de teoría poética. La relativa proliferación de estas menciones se debe, además de las recientes ediciones de sus obras, al éxito del Persiles cervantino y de otra novela que se sirve del modelo heliodoriano y que, desde 1621 , año de su aparición en latín, se reedita constantemente en toda Europa: Argenis y Poliarco de John Barclay, obra que es traducida al español por Pellicer y G. del Corral en dos versiones distintas que se editan al mismo tiempo, en $1626^{44}$. También en esos mismos años aparecerán lo que podemos considerar imitaciones de la novela griega en España, novelas como la Historia de Hipólito y Aminta de Quintana (1627), la Historia de las fortunas de Semprilis y Genorodano de Enríquez de Zúñiga (1629) o Eustorgio y Clorilene. Historia moscóvica de Suárez de Mendoza (1629), obras que reciben en sus preliminares la denominación de "poemas", como ocurre con obras tan dispares como el Gerardo de Céspedes, La Dorotea de Lope o la Peregrinación sabia de Salas Barbadillo.

Es ésta sin duda la idea más repetida en estos años: en distintos textos de la época aparecerán menciones a Heliodoro y Aquiles Tacio en la misma línea tópica que ya hemos señalado en Soto de Rojas, la dignidad de la poesía en

en buena parte de su Historia etiópica nos hizo desear los nombres de la donçella y el mançebo, sujetos principales de su Poema, que al fin supimos ser Theágenes y Caricleam. En Miguel ARTIGAS, Don Luis de Góngora y Argote. Biografia y estudio crítico, Madrid, Tipografia de la Revista de Archivos, 1925, Apéndice VII, p. 406.

42 «Así, en estas Soledades, si miramos al modo de decir, se ha de reducir al sublime; si a la materia, a aquel género de Poema de que constaria la Historia ethibpica de Heliodoro si se redujera a versos». En ANA MARTtNeZ, La batalla en torno a Góngora, Barcelona, A. Bosch, 1978, p. 141.

43 «Nuestro poeta comienza por una tempestad, de que un mozo escapa en una tabla. Y si el Antidoto condena este modo de dar principio ex abrupto, sepa que con acuerdo tejió así la narración [...]. Asf Virgilio dirigio su obra [...]. Y Heliodoro en la Historia etiopica hizo lo mismow. Tomamos el texto de A. CRUZ, «Hacia un nuevo enfoque de las Soledades», art. cit., p. 88.

$44 \mathrm{La}$ asociación de las novelas de Heliodoro y Barclay en los preliminares de ambas traducciones es constante. Pero aparece también en otros textos. Vid., por ejemplo, la aprobación de Lope en la obra de Pedro de Castro y anaya, Auroras de Diana, ed. de L. González Simón, Madrid, C.S.I.C., 1948, p. 23. 
prosa. Lo más destacado de alguno de estos textos es la creciente dignificación de obras renacentistas o barrocas mediante su equiparación con los modelos de la antiguedad. Asi, Lope de Vega $(1624)^{45}$, Colmenares $(1624)^{46}$, y Pellicer $(1625)^{47}$ continúan una corriente que, iniciada con Lopez Pinciano, llegará hasta el siglo XVIII, momento en que autores o tratadistas empiezan a rechazar la denominación de épica en prosa para la novela ${ }^{48}$.

Ya en la década de 1630-1640 se inicia el declive del peso de la autoridad de Heliodoro y Aquiles Tacio en la preceptiva española. Aunque señalemos otros ejemplos, creemos que ha pasado el momento de mayor esplendor de dichos novelistas. En la Nueva idea de la tragedia antigua (1633) de J. A. González de Salas, el texto más importante de este período, tan sólo hemos encontrado una única mención, dedicada a los modos de la mímesis:

Esto, añado io, se confirma mucho con el juicio estimable de el grande crítico Phocio, quando haciéndole en su Biblioteca de la Historia amorosa de Heliodoro la llamó dramática, siendo de la misma suerte formada su contextura que la de el poema: de interlocutores, digo, i de el auctor ${ }^{49}$,

45 En una de sus epistolas de La Circe (Obras poéticas, ed. cit., p. 1259) sostiene que «la esencia de la poesia no es el verso, como se ve en Heliodoro, Apuleyo, las prosas de Sannazaro y piscatorias de San Martino».

${ }^{46}$ En su polémica con Lope, sostiene que «siendo pues la esencia de la poética la ficción, nadie medianamente entendido negará que sean poemas la ficción de Heliodoro, casi todos los Diálogos de Luciano, la Transformación de Apuleyo y en nuestra lengua el prudente Guzmán de Alfarache, el desgraciado Gerardo y cuantos libros de caballerías avivaron la invención española, hasta su Herodes Don Quijote» (en A. PORQueras, op. cit., p. 112).

${ }^{47}$ En uno de los textos académicos editados por J. SÁNCHEZ (op., cit., p. 90) afirma: «ay poemas en prosa, como son Ismenes e Ismenia, Teágenes y Cariclea, Leucipe y Clitofonte, Argenis y Poliarcon. Esta es, por cierto, una de las escaśsimas menciones que conocemos a la novela de Eustacio Macrembolita.

48 Para la postura de Fielding o el padre Isla, vid. J. Álvarez BaRRIENTos, «Algunas ideas sobre teoría de la novela en Inglaterra y España en el siglo XVIII», Anales de Literatura Española, 2 (1983), pp. 5-23. Recordemos también que Luzán rechaza dicha denominación para una de las obras mencionadas por Colmenares. En La Poética (ed. de R. P. SEBold, Barcelona, Labor, 1977, p. 558) sostiene: «tampoco sera epopeya ninguna obra escrita en prosa, por faltarle el requisito del verso; dígolo porque me acuerdo de haber visto un librillo intitulado Historia trágica del español Gerardo, a quien se anade también el título de epopeya en prosa».

49 J. A. GonZAl.eZ de SAlAs, Nueva idea de la tragedia antigua, Madrid, Francisco Martínez, 1633, p. 199. En efecto, Photius (Biblotheque, ed. de RENE HENRY, Paris, Les Belles lettres, 1959,

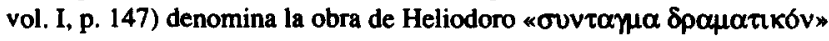


referencia idéntica a la que encontraremos en la versión ampliada de esta obra, la Ilvstración al libro De Poetica de Aristóteles Stagirita ${ }^{50}$.

Las otras menciones que podemos señalar en estos años, no son muy numerosas y tienen un carácter tópico. Es el caso de Faria y Sousa en su comentario a Los Lusiadas de Camoens (1639), donde se refiere al principio in medias res $^{51}$. En cambio, hemos de constatar la aparición de ciertas críticas hacia la obra de Heliodoro. Si Lope mantenía una actitud polivalente, entre la franca admiración y las reticencias ante el contenido sensual de una novela que «más enciende que entretiene» según indica en La Dorotea $(1632)^{52}$, será uno de sus discípulos, Tirso de Molina, quien ataque el carácter ficticio de Las etiópicas en su Deleitar aprovechando (1635), poniéndola al mismo nivel que la novela corta italiana, la narrativa barroca y, lo que nos parece una acusación más grave, los denostadísimos libros de caballerías:

${ }^{50}$ Ilvstración al libro De Poetica de Aristóteles Stagirita (s.l., s.i., s.a., p. 199). Por otro lado, en ninguna de las traducciones españolas de Aristóteles se encuentra mención alguna a los novelistas clásicos: ni en las más fieles al texto griego, las de Alonso Ordónez das Seyjas, La poética de Aristóteles dada a nvestra lengva castellana (Madrid, 1626) y La arte de Rhetorica de Aristóteles. El libro de la poética de Aristóteles, vertidas a la verdad de la letra del texto griego por el maestro Vicente Marinerio Valentino (manuscrito 9973 de la BNM, fechado en abril de 1630), ni tampoco en la versión más libre, con reflexiones sobre literatos latinos, italianos y españoles, debida a Juan Pablo MátIR Rizo, Poética de Aristóteles traducida de latín, manuscrito de 1623 (ed. moderna de M. Newels, Koln und Opladed, Westdeustscher Verlag, 1965).

51 «Raro es el poema épico, lírico, o cómico, o trágico, en verso o en prosa de los antiguos maestros que no empiece así. Así el gran Heliodoro en su Teágenes, con cuantos le imitaron". Unas líneas después aparece una afirmación polémica que hay que poner en relación con la supremacía destacada por López Pinciano respecto a los otros modelos épicos: «a algunos parece bien que el poema heroico empiece por el principio puntual del caso. Ese acierto sería más seguro si los maestros lo hubieran enseñado asi, pero no es así realmente, porque el querer porfiar que Homero y Virgilio comenzaron sus poemas por el principio será ocasión de mostrar ingenio, mas no verdad. Porque realmente comienzan muy lejos del principio, y por eso escuso argumentos*. En A. PorQUERAS MAYO, op., cit., pp. 251.

52 LoPE DE VEGA, La Dorotea (ed. de J. M. Blecua, Madrid, Universidad de Puerto Rico-Revista de Occidente, 1955, p. 281). También en Pedro de Urdemalas encontramos un pasaje que puede ponerse en relación con las críticas a la narrativa de entretenimiento como incitadora de la sensualidad de los lectores que abundan en el siglo XVI: «QQué es aquesto que he lerdo/ que tiene tanto poder? / ¿Qué escrito pudo mover / mi enamorado sentido? / ¿Qué griego es este que amó / la divina Clariquea? /[...] A Teágenes adoro, / envidioso de que sea / amante de Clariquea / en el libro de Heliodoro». Cit. por José LARA GARRIDO, «El peregrino en su patria de Lope de Vega desde la poética del romance griego*, Analecta Malacitana, VII, I (1984), p. 30. La postura negativa de Lope anticipa las virulentas críticas de B. Lamy dirigidas al efecto de Las etiopicas sobre sus lectores. En varias páginas de las Nouvelles reflexions sur l'Art Poëtique (Paris, Pralard, 1668, pp. 45-47, 63 y 104) rechaza dicha novela, cuya «lecture remplit-elle [...] l'esprit d'images licentieuses, qui corrompent \& qui échauffent l'imagination des lecteurs». 
Si tanto se recrea el común gusto con lo peregrino de los cuentos, lo enmarañado de los amores, lo temerario de la valentía, lo ingenioso de las trazas y lo quimérico de las auenturas, ni en cuanto el Bocacio, el Giraldo, el Vandelo y otros escriuieron en toscano, Eliodoro en griego, en portugués Fernán Méndez Pinto, Barclayo en Francia, los autores de los Belianises, Febos, Primaleones, Dianas, Guzmanes de Alfarache, Gerardos y Persiles en nuestro castellano, pueden compararse (puesto que todos son patrañas) con los sucessos portentosos, raros y verdaderos destos tres sugetos ${ }^{53}$.

También de estos mismos años son las primeras alusiones burlescas a la novela de Heliodoro que indican que, como en tantas otras ocasiones, el Barroco acaba perdiendo el respeto hacia las autoridades de la antigüedad, sea pintanto la coquetería de Cariclea, como hace Lope en El laurel de Apolo $(1629)^{54}$, las «dos higas para Heliodoro / y el Barclayo» que les dedica un personaje en Las muñecas de Marcela (1636) de Cubillo de Aragón ${ }^{55}$ o la descripción de Teágenes como un alocado galán de comedia en Los hijos de la fortuna. Teágenes y Clariquea (1638), adaptación teatral realizada por Pérez de Montalbán ${ }^{56}$.

Todavía Faria y Sousa aludirá nuevamente a la poesía en prosa en los preliminares de su Fuente de Aganipe (1646), aunque tampoco ahorre alguna crítica al novelista ${ }^{57}$. Pero hay que esperar a la Agudeza y arte de ingenio (1648) de Baltasar Gracián para volver a encontrar una preceptiva poética que dedique un

53 TIRso de Molina, Deleytar aprovechando, Madrid, Imprenta Real, 1635, dedicatoria.

54 Aludiendo a la traducción en quintillas de la novela de Heliodoro realizada por Collado del Hierro, de la que sólo se conserva un fragmento, escribe Lope con el tono burlesco de Burguillos: «Hermosa Clariquea, / Más debéis a su pluma que a Heliodoro, / O permitid que sea / Su verso en vuestra prosa esmalte en oro; / Que más vuestro galán favorecido / Collado que Teágenes ha sido, / Pues siendo tan antigua os ha quitado / Los anos con haberos remozado; / Que no hay tales servicios ni placeres / Como quitar la edad a las mujeres». En Obras sueltas (BAE, XXXVIII), Madrid, Rivadeneyra, 1872, p. 218.

55 Alvaro Cubillo de Aragon, Las muñecas de Marcela, ed. de A. Valbuena, Madrid, Alcalá, 1966, p. 130.

56 Fris6n, el escudero del protagonista, se sorprende de «que un amo que Dios me dio, / [...] sea $\tan$ loco, $\tan$ vano, / tan tronera, $\tan$ orate, / y $\tan$ cascabel, que sin / conocer padre ni madre, / señal que fue concebido / a escote entre muchos padres, / enamore a Cariclear. J. PÉREZ DE MOLTALBAN, Los hijos de la fortuna, Barcelona [s.i, s.a.], p. 7.

${ }^{57}$ En dos de los textos preliminares que acompantan sus poesías en la Fuente de Aganipe (Madrid, Carlos Sánchez Bravo, 1646) encontramos las siguientes apreciaciones: «Poesía es Teágenes con ser en prosa; con ser en verso no es poesía una multitud de libros que corren plaça de poemas» (Prólogo, párrafo 30); «Tampoco es de importancia a la poesía el verso o número métrico. Puédela aver altíssima en prosa, como lo es Teagenes y Cariclea. En prosa están traduzidos Home- 
espacio considerable a Heliodoro, si no por el número de menciones, al menos por la admiración que revelan ${ }^{58}$. Se trata de dos reflexiones sobre aspectos ya desarrollados por López Pinciano: la clasificación de la epopeya según la materia argumental (heroica, amorosa y humilde) ${ }^{59}$ y el rechazo del deus ex machina en la resolución de una trama tan complicada como la de Las etiópicas. $^{60}$. Después de Gracián, no hemos localizado otras menciones a los novelistas griegos en textos de poética.

En síntesis, creemos haber destacado suficientemente la desigual atención a los novelistas griegos en nuestras reflexiones sobre poética que podemos resumir en las siguientes aspectos: 1) la ausencia casi absoluta de Heliodoro y Aquiles Tacio en las preceptivas españolas más destacadas; 2) la excepción que constituye la Philosophía antigua poética de López Pinciano quien recoge aportaciones anteriores, pero sobre todo, desarrolla un punto de vista personal y señala los aspectos más relevantes de los modelos griegos; 3 ) la repetición tópica en textos menores de dos ideas (poesía en prosa e inicio in medias res) que, directa o indirectamente, proceden en su mayoria de Lopez Pinciano, en un período de tiempo bastante limitado, y 4) por último, y ya hacia el final del período estudiado, la existencia de criticas a ciertos aspectos de dichas obras o perspectivas burlescas respecto a las mismas, lo que impide hablar de una acogida unánime y entusiasta de Heliodoro y Aquiles Tacio.

ro i Virgilio i tan poetas son en ella como en sus metros» («Advertencias...», párrafo 6). Curiosamente, también aparece aquí una de las pocas críticas estilísticas que conocemos: «Del Teágenes de Heliodoro, mejores que los cinco últimos [libros, son] los cinco primeros" (ibid., párrafo 25).

58 Recordemos que en el prólogo de El criticón afirma que ha pretendido imitar «los empeños de Heliodoro». Obras completas, ed. de A. del Hoyo, Madrid, Aguilar, 1967³ , p. 251.

59 «Unas son heroicas [...], otras son amorosas, así Heliodoro, en los trágicos sucesos de Theágenes y Clariquea, describe elegantemente la tiranía del amor profano y sus violencias». En cuanto a la epopeya humilde, paradoja plenemente barroca, tiene su mejor ejemplo en el Guzmán de Alfarache de Mateo Alemán. Ibid., p. 479.

${ }^{60}$ Destaca Gracián la habilidad necesaria para «hallar el único medio con que salir de la dificultad, en descubrir el raro modo con que desempeñarse [...] vanse empeñando las épicas ficciones, novelas, comedias y tragedias, vanse empeñando los sucesos, y apretando los lances, de tal suerte que parecen a veces no poder tener salida. [...] Mas aquí está el primor del arte, y la valentía de la inventiva, en hallar medio extravagante, pero verisímil con que salir del enredado laberinto». Esto es lo que puede observarse en la novela de Heliodoro, modelo indiscutible de la construcción novelística: así hace «el griego Heliodoro, la de Cariclea dando que imitar al inglés Barclayo en su Argenis, y a muchos otros». lbid., pp. 440-442. 